\title{
In Vitro Suppression of Soilborne Plant Pathogens by Coir
}

\section{Naveen Hyder, James J. Sims, and Stephen N. Wegulo ${ }^{1,2}$}

ADDITIONAL INDEX WORDS. potting medium, disease suppressive properties, soilborne

Summary. Experiments conducted in vitro showed that coir [coconut (Cocos nucifera) mesocarp pith] suppressed growth of soilborne plant pathogens. Mycelial growth of Phytophthora capsici on potato dextrose agar (PDA) amended with an unsterilized coir suspension was strongly inhibited regardless of suspension concentration. Growth of $P$. capsici on PDA amended with a filter-sterilized coir suspension was uninhibited. Growth of Fusarium solani on water agar (WA) amended with unautoclaved coir was completely inhibited. Growth of F. solani on WA amended with autoclaved coir was uninhibited. Aspergillus terreus recovered from coir inhibited mycelial growth of various soilborne pathogens by up to $75 \%$. The results from this study suggest that coir has the ability to suppress soilborne plant pathogens in vitro and this ability is largely due to microorganisms associated with the substrate.

C oir has become popular as a potting medium in greenhouse and nursery production. Qualities of coir that make it a good peat substitute include high water holding capacity, excellent drainage, physical resilience, and the fact that it is a renewable resource (Masago et al., 1977; Meerow, 1994; Prasad, 1997). It has been demonstrated that coir can suppress certain soilborne plant pathogens (Candole and Evans, 2004; van der Gaag and Wever, 2005). Combining the diseasesuppressive properties of coir with other management strategies such as fungicide application in an integrated pest management program may result in more effective and less costly management of soilborne diseases in greenhouse and nursery production.

Suppressive substrates reduce soilborne diseases by their physical and/or chemical properties such as drainage, $\mathrm{pH}$, and chemical inhibitors (Hoitink and Fahy, 1986; van der Gaag and Wever, 2005) or by supporting beneficial microorganisms

We thank Maren Klich, Rabin Olatinwo, and James Bornemann for assistance with pathogen identification. We thank Miguel Vilchez for technical assistance, and we are indebted to Frank Chavez and Michael Stanghellini for providing coir and fungal cultures, respectively. We also are grateful to the California Association of Nursery and Garden Centers for partial funding of this research.

Department of Plant Pathology, University of California, Riverside, CA 92521

${ }^{1}$ Current address: Department of Plant Pathology, University of Nebraska, 448 Plant Science Hall, Lincoln, NE 68583.

${ }^{2}$ Corresponding author. E-mail: swegulo2@unl.edu. that lower disease incidence or severity by mechanisms such as competition, antibiosis, parasitism, or induction of systemic resistance (Han et al., 1998; Hoitink and Boehm, 1999). In addition to coir, soil substitutes such as peat and hardwood bark also have been shown to suppress certain plant diseases (Hoitink and Fahy, 1986). Unautoclaved rockwool recolonized by indigenous microflora was suppressive to Pythium aphanidermatum (Postma et al., 2000).

Horticultural studies suggest that coir may be a suitable organic component in soilless media and is better than most other alternatives, including rock wool (Islam et al., 2002; Meerow, 1994; Meerow, 1995). Trials using tomato (Solanum lycopersicum) as a test crop indicated that coir gave better crop productivity Population densities of Phytophthora capsici, P. nicotianae, P. aphanidermatum, and $P$. ultimum were reduced by $76 \%, 80 \%, 32 \%$, and $11 \%$, respectively, when tomatoes were grown in coir compared with peat. than rockwool (Islam et al., 2002).
In the same study, damping-off incidence was reduced by $88 \%, 90 \%$, and $41 \%$ for P. capsici, P. nicotianae, and $P$. aphanidermatum, respectively (Candole and Evans, 2004). Research has not been done to determine what causes coir to suppress plant pathogens. The objective of this study was to evaluate, in vitro, the ability of coir to suppress soilborne plant pathogens.

\section{Materials and methods}

Fungal cultures. Fusarium solani was isolated from infected gerbera (Gerbera jamesonii) seedlings and maintained on modified NashSnyder medium (Nash and Snyder, 1962). P. capsici was recovered from recycled nursery water and maintained on a Phytophthora-selective (PARPH) medium (Masago et al., 1977; Tsao and Guy, 1977). Cultures of $P$. parasitica, P. capsici, P. citricola, $P$. cinnamomi, $P$. cactorum, and P. cryptogea were provided by $\mathrm{M}$. Stanghellini (University of California, Riverside). Sclerotinia sclerotiorum, Rhizoctonia sp., Cylindrocladium sp., Pythium sp., and Verticillium sp. were isolated from a variety of infected greenhouse, nursery, and landscape plants brought to S. Wegulo's laboratory (University of California, Riverside) for diagnosis. All cultures except F. solani and Phytophthora species were maintained on potato dextrose agar (PDA) in 9-cm-diameter petri plates and were stored at $4{ }^{\circ} \mathrm{C}$ until needed for experiments. Fungal cultures used in all experiments were grown on PDA, half-strength PDA (1/2-PDA), or water agar (WA) in 9 -cm-diameter petri plates.

SOURCE OF COIR. The coir used in this study was obtained from a commercial supplier (Cal-Native Plants, Menifee Valley, CA). Coconut husk was collected from areas surrounding the city of Tecoman, state of Colima, Mexico, processed into

\begin{tabular}{llll}
\hline $\begin{array}{l}\text { Units } \\
\begin{array}{l}\text { To convert U.S. to SI, } \\
\text { multiply by }\end{array}\end{array}$ & U.S. unit & SI units & $\begin{array}{l}\text { To convert SI to U.S., } \\
\text { multiply by }\end{array}$ \\
\hline 29.5735 & fl oz & $\mathrm{mL}$ & 0.0338 \\
3.7854 & gal & $\mathrm{L}$ & 0.2642 \\
2.54 & inch(es) & $\mathrm{Cm}$ & 0.3937 \\
25.4 & inch(es) & $\mathrm{Mm}$ & 0.0394 \\
1 & micron & $\mu \mathrm{m}$ & 1 \\
28.3495 & $\mathrm{oz}$ & $\mathrm{g}$ & 0.0353 \\
$\left({ }^{\circ} \mathrm{F}-32\right) \div 1.8$ & ${ }^{\circ} \mathrm{F}$ & ${ }^{\circ} \mathrm{C}$ & $\left(1.8 \times{ }^{\circ} \mathrm{C}\right)+32$
\end{tabular}


coir in the same city, and then shipped to F. Chavez (Cal-Native Plants). Coir used in all experiments was not retted. Retting is a process used to extract quality coir fiber from coconut husk (Neena et al., 2007). It involves soaking coconut husk in water to decompose the binding materials that hold the fibers together in the husk (Zachariah and Muralidharan, 2002).

Evaluation of MYCelial GROWTH OF $P$. CAPSICI ON MEDIUM AMENDED WITH A COIR SUSPENSION. Seventy-two grams of dry coir was soaked in $1 \mathrm{~L}$ of distilled water and set on a laboratory bench for 3, 6, 9, or $12 \mathrm{~d}$ at room temperature. For each soaking period, $300 \mathrm{~mL}$ of suspension was collected by filtering the suspension through several layers of cheesecloth. One half of the suspension was filter-sterilized with a $0.2-\mu \mathrm{m}$ filter membrane and the other half was left unsterilized. A 7 $\mathrm{mm}$-diameter plug of $P$. capsici from the edge of an actively growing culture was transferred to the center of each petri plate (experimental unit) with $15 \mathrm{~mL}$ of PDA amended with the suspension at $0.1,0.2$, and $0.4 \mathrm{~mL}$ of suspension per milliliter of PDA. For each concentration, the suspension was measured with a micropipette and transferred to autoclaved PDA that had cooled down to $\approx 40{ }^{\circ} \mathrm{C}$ in a laminar flow hood. A magnetic stirrer was used to mix the suspension with the PDA. Petri plates were incubated at $22{ }^{\circ} \mathrm{C}$ in a 12-h light-dark cycle. The experimental design was a split-split plot in randomized complete blocks with three replications. Suspension concentrations were the main plots, filter-sterilization treatments (sterilized and unsterilized) were the subplots, and soaking periods were the subsubplots. Mycelial radius was measured $6 \mathrm{~d}$ after initiation of cultures and was used to calculate myceliumcovered area. The experiment was conducted twice.

Evaluation of Mycelial GROWTH OF F. SOLANI ON COIRAMENDED MEDIUM. Dry coir was ground to powder using a No. I Wiley mill (Arthur H. Thomas, Philadelphia, PA) with a l-mm-diameter screen. Five grams of autoclaved or unautoclaved ground coir, $0.25 \mathrm{~g}$ of potassium chloride, $0.005 \mathrm{~g}$ of ferrous sulfate, $5 \mathrm{~g}$ of yeast extract, 0.25 $\mathrm{g}$ of magnesium sulfate, $0.25 \mathrm{~g}$ of calcium nitrate, and $0.125 \mathrm{~g}$ of monopotassium phosphate were incorporated with a magnetic stirrer into $500 \mathrm{~mL}$ of WA that had cooled down to $\approx 40{ }^{\circ} \mathrm{C}$ in a laminar flow hood. Twenty milliliters of the amended WA was poured into each of four petri plates. WA amended with $5 \mathrm{~g}$ of peat or $5 \mathrm{~g}$ of malt extract was similarly prepared. There were six treatments in the experiment: WA amended with autoclaved coir, WA amended with unautoclaved coir, WA amended with autoclaved peat, WA amended with unautoclaved peat, WA amended with autoclaved malt extract, and WA amended with unautoclaved malt extract. The malt extract treatments served as controls. Peat was included because microbial antagonists have been shown to be associated with it (Hoitink and Boehm, 1999; Hoitink and Fahy, 1986). A 7-mm-diameter plug of $F$. solani from the edge of an actively growing culture was placed in the center of each petri plate with the amended medium. The plates were incubated at $25^{\circ} \mathrm{C}$ in a 12 -h lightdark cycle. Mycelial radius was measured $7 \mathrm{~d}$ after initiation of cultures and was used to calculate myceliumcovered area. The experimental design was a split plot in randomized complete blocks with four replications. Autoclave treatments served as the main plots and substrates (coir, peat, and malt extract) served as the subplots. The experiment was conducted three times.

INHIBITION OF MYCELIAL GROWTH OF SOILBORNE PATHOGENS BY ASPERGILLUS TERREUS. In the course of this study, $A$. terreus was consistently isolated from coir. As a contaminant, it was observed to inhibit mycelial growth of $P$. capsici and $F$. solani. An experiment was conducted to investigate the inhibitory effect of $A$. terreus on 12 soilborne plant pathogens. The pathogens were $P$. parasitica, $P$. capsici, $P$. citricola, $P$. cinnamomi, $P$. cactorum, P. cryptogea, F. solani, S. sclerotiorum, Rhizoctonia sp., Cylindrocladium sp., Pythium sp., and Vericillium sp.

An isolate of $A$. terreus was recovered from coir by sprinkling ground coir dust on $1 / 2$-PDA. Cultures of the fungus were transferred to separate petri plates, each containing $15 \mathrm{~mL}$ of $\mathrm{l} / 2$-PDA. A $7-\mathrm{mm}^{-}$ diameter plug of this isolate was placed near the edge of a petri plate containing $15 \mathrm{~mL}$ of $1 / 2$-PDA. A 7 mm-diameter plug of each of the 12 test pathogens was taken from the edge of an actively growing culture and placed near the opposite edge of the petri plate containing an $A$. terreus plug. Petri plates were maintained in an incubator at $22{ }^{\circ} \mathrm{C}$ with a 12-h light-dark cycle. The distance from the plug of each pathogen to the edge of the zone of inhibition (caused by $A$. terreus) or the edge of the $A$. terreus culture was measured $14 \mathrm{~d}$ after initiation of cultures.

Each pathogen also was concurrently grown on control $1 / 2-\mathrm{PDA}$ plates without an $A$. terreus plug. A 7-mm-diameter plug of each pathogen was placed on the edge of a petri plate and the distance from the plug to the actively growing edge of the mycelial culture was measured $14 \mathrm{~d}$ after initiation of cultures. The percentage of inhibition of growth of each pathogen was calculated as $[(a-b) / a] \times 100$, where $a$ is the distance from the 7-mm-diameter plug of the pathogen at the edge of the control plate to edge of the mycelial culture and $b$ is the distance from the 7-mm-diameter plug of the pathogen at the edge of the plate with an $A$. terreus plug to the edge of the zone of inhibition (caused by $A$. terreus) or the edge of the $A$. terreus culture. The test pathogens served as treatments and were arranged in randomized complete blocks with three replications (three plates with $A$. terreus plus the pathogen and three control plates with the pathogen alone). The experiment was conducted twice.

Data Analysis. The GLM procedure of SAS (version 8; SAS Institute, Cary, NC) was used to analyze data. Data from replicate experiments were combined or not combined based on homogeneity or heterogeneity, respectively, of error variances determined from the $F$-ratio test or Bartlett's test (Gomez and Gomez, 1984). The mycelium-covered area was calculated as $p i \times R^{2}-p i \times r^{2}$, where $R$ is the radius of the fungal culture in the 9-cm-diameter petri plate and $r$ is the radius of the 7 $\mathrm{mm}$-diameter mycelial plug placed at the center of the petri plate. Fisher's least significant difference test at $P=$ 0.05 (Gomez and Gomez, 1984) was 
used to compare pairs of treatment means.

\section{Results}

EVALUATION OF MYCELIAL GROWTH OF $P$. CAPSICI ON MEDIUM AMENDED WITH A COIR SUSPENSION. In Expt. 1, $F$ values for coir suspension concentration $(P<0.0001)$, filtration $(P<0.0001)$, soaking period $(P<0.0084)$, and concentration by filtration interaction $(P<0.001)$ were highly significant, whereas $F$ values for concentration by soaking period, filtration by soaking period, and the three-way interaction were not significant $(P>0.05)$. In Expt. $2, F$ values for all three treatments and their interactions were highly significant $(P<0.0009)$, except for the threeway interaction $(P=0.0832)$.

The unsterilized coir suspension strongly inhibited mycelial growth of $P$. capsici at all concentrations in Expts. 1 and 2 (Table 1 ). In the filter-sterilized coir suspension treatments in Expts. 1 and 2, there was no significant difference in myceliumcovered area between the lowest (0.1 mL suspension per milliliter of PDA) and second lowest $(0.2 \mathrm{~mL}$ suspension per milliliter of PDA) concentrations of the suspension. However, the mycelium-covered area was significantly $(P=0.05)$ greater at the highest concentration $(0.4 \mathrm{~mL}$ suspension per milliliter of PDA) compared with the two lower concentrations (Table 1 ).

The effect of soaking period on mycelial growth of $P$. capsici varied among coir suspension concentrations (Table 2). At the lowest concentration $(0.1 \mathrm{~mL}$ suspension per milliliter of PDA), there were no significant differences in the myceliumcovered area among soaking periods in Expts. 1 and 2. At the second lowest concentration $(0.2 \mathrm{~mL}$ suspension per milliliter of PDA), the mycelium-covered area in the $6-\mathrm{d}$ soaking period was significantly $(P=$ 0.05 ) greater than the mycelium-covered area in the 3 - $\mathrm{d}$ soaking period in both experiments. At the highest concentration $(0.4 \mathrm{~mL}$ suspension per milliliter of PDA), the myceliumcovered area in the 9 -d soaking period was significantly $(P=0.05)$ less than the mycelium-covered area in the 6 - $d$ soaking period in both experiments.
In the unsterilized coir suspension treatment, mycelial growth was strongly inhibited in Expts. 1 and 2, regardless of soaking period (Table 3 ). There were no significant differences at $P=0.05$ in the mycelium-covered area among soaking periods in both experiments; however, the myceliumcovered area was less in the 9- and 12$\mathrm{d}$ compared with the 3 - and 6-d soaking periods. Colonies of various microorganisms were visible by day 7 after initiation of cultures. Three of these microorganisms were identified as A. terreus, Paecilomyces sp., and Trichoderma sp. The rest of the microorganisms were not identified.

In the filter-sterilized coir suspension treatment, mycelial growth was

Table 1. Mycelium-covered area of Phytophthora capsici on potato dextrose agar (PDA) amended with an unsterilized or a filter-sterilized coir suspension at three concentrations.

\begin{tabular}{|c|c|c|c|c|c|c|}
\hline \multirow[b]{3}{*}{$\begin{array}{l}\text { Suspension concn } \\
\left(\mathrm{mL} \cdot \mathrm{mL}^{-1} \mathrm{PDA}\right)\end{array}$} & \multicolumn{6}{|c|}{ Mycelium-covered area $\left(\mathrm{mm}^{2}\right)^{\mathrm{z}}$} \\
\hline & \multicolumn{3}{|c|}{ Sterilization: Expt. 1} & \multicolumn{3}{|c|}{ Sterilization: Expt. 2} \\
\hline & Unsterilized & $\begin{array}{c}\text { Filter- } \\
\text { sterilized }\end{array}$ & $\operatorname{LSD}^{\mathrm{y}}$ & Unsterilized & $\begin{array}{c}\text { Filter- } \\
\text { sterilized }\end{array}$ & LSD \\
\hline 0.1 & 1.3 & 30.0 & 1.8 & 1.3 & 31.6 & 2.3 \\
\hline 0.2 & 1.2 & 31.4 & 1.8 & 1.3 & 30.7 & 2.3 \\
\hline 0.4 & 1.9 & 41.7 & 1.8 & 2.1 & 43.3 & 2.3 \\
\hline LSD & 1.7 & 1.7 & - & 1.8 & 1.8 & - \\
\hline
\end{tabular}

${ }^{\mathrm{z}}$ Mycelium-covered area was measured $6 \mathrm{~d}$ after initiation of cultures; $1 \mathrm{~mm}^{2}=0.0016$ inch $^{2}$. 'Fisher's least significant difference at $P=0.05$.

Table 2. Mycelium-covered area of Phytophthora capsici on potato dextrose agar (PDA) amended with a coir suspension at three concentrations and four soaking periods in distilled water.

\begin{tabular}{|c|c|c|c|c|c|c|c|c|c|c|}
\hline \multirow{3}{*}{$\begin{array}{l}\text { Suspension concn } \\
\left(\mathrm{mL} \cdot \mathrm{mL}^{-1} \mathrm{PDA}\right)\end{array}$} & \multicolumn{10}{|c|}{ Mycelium-covered area $\left(\mathrm{mm}^{2}\right)^{\mathrm{z}}$} \\
\hline & \multicolumn{5}{|c|}{ Soaking period (d): Expt. 1} & \multicolumn{5}{|c|}{ Soaking period (d): Expt. 2} \\
\hline & 3 & 6 & 9 & 12 & $\operatorname{LSD}^{y}$ & 3 & 6 & 9 & 12 & LSD \\
\hline 0.1 & 16.1 & 16.0 & 14.8 & 15.5 & 2.1 & 16.6 & 17.0 & 15.8 & 16.3 & 1.3 \\
\hline 0.2 & 15.4 & 18.0 & 16.0 & 15.8 & 2.1 & 14.8 & 17.3 & 15.4 & 16.5 & 1.3 \\
\hline 0.4 & 22.5 & 23.4 & 20.4 & 20.9 & 2.1 & 23.2 & 24.5 & 21.3 & 21.8 & 1.3 \\
\hline LSD & 2.2 & 2.2 & 2.2 & 2.2 & 一 & 1.4 & 1.4 & 1.4 & 1.4 & - \\
\hline
\end{tabular}

${ }^{2}$ Mycelium-covered area was measured $6 \mathrm{~d}$ after initiation of cultures; $1 \mathrm{~mm}^{2}=0.0016$ inch $^{2}$.

${ }^{\text {y}}$ Fisher's least significant difference at $P=0.05$

Table 3. Mycelium-covered area of Phytophthora capsici on potato dextrose agar amended with an unsterilized or a filter-sterilized coir suspension that formed during four soaking periods in distilled water.

\begin{tabular}{|c|c|c|c|c|c|c|c|c|c|c|}
\hline \multirow[b]{3}{*}{ Sterilization } & \multicolumn{10}{|c|}{ Mycelium-covered area $\left(\mathrm{mm}^{2}\right)^{\mathrm{z}}$} \\
\hline & \multicolumn{5}{|c|}{ Soaking period (d): Expt. 1} & \multicolumn{5}{|c|}{ Soaking period (d): Expt. 2} \\
\hline & 3 & 6 & 9 & 12 & $\mathrm{LSD}^{\mathrm{y}}$ & 3 & 6 & 9 & 12 & LSD \\
\hline Unster & 1.8 & 1.8 & 1.1 & 1.1 & 1.7 & 2.0 & 2.0 & 1.1 & 1.1 & 1.0 \\
\hline Filter-sterilized & 34.2 & 36.6 & 33.1 & 33.6 & 1.7 & 34.4 & 37.3 & 34.0 & 35.3 & 1.0 \\
\hline LSD & 1.8 & 1.8 & 1.8 & 1.8 & 一 & 1.6 & 1.6 & 1.6 & 1.6 & 一 \\
\hline
\end{tabular}

${ }^{\mathrm{z}}$ Mycelium-covered area was measured $6 \mathrm{~d}$ after initiation of cultures; $1 \mathrm{~mm}^{2}=0.0016$ inch $^{2}$

'Fisher's least significant difference at $P=0.05$. 
Table 4. Mycelium-covered area of Fusarium solani on water agar amended with autoclaved or unautoclaved coir, peat, or malt.

\begin{tabular}{|c|c|c|c|c|c|c|c|c|c|c|c|c|}
\hline \multirow{3}{*}{$\begin{array}{l}\text { Autoclave } \\
\text { treatment }\end{array}$} & \multicolumn{12}{|c|}{ Mycelium-covered area $\left(\mathrm{mm}^{2}\right)^{\mathrm{z}}$} \\
\hline & \multicolumn{4}{|c|}{ Expt. I } & \multicolumn{4}{|c|}{ Expt. 2} & \multicolumn{4}{|c|}{ Expt. 3} \\
\hline & $\overline{\text { Coir }}$ & Peat $^{\mathrm{y}}$ & Malt $^{x}$ & LSD $^{\mathrm{w}}$ & $\overline{\text { Coir }}$ & Peat & Malt & $\overline{\text { LSD }^{\mathrm{w}}}$ & $\overline{\text { Coir }}$ & Peat & Malt & LSD $^{\mathrm{n}}$ \\
\hline Autoclaved & 38.1 & 37.5 & 35.7 & 1.1 & 38.1 & 38.1 & 37.8 & 0.2 & 36.4 & 38.1 & 38.1 & 3.7 \\
\hline Unautoclaved & 0.0 & 0.0 & 37.0 & 1.1 & 0.0 & 0.0 & 38.1 & 0.2 & 0.0 & 0.0 & 37.0 & 3.7 \\
\hline LSD & 1.4 & 1.4 & 1.4 & - & 0.3 & 0.3 & 0.3 & - & 3.8 & 3.8 & 3.8 & - \\
\hline
\end{tabular}

${ }^{\mathrm{z}}$ Mycelium-covered area was measured $7 \mathrm{~d}$ after initiation of cultures; $1 \mathrm{~mm}^{2}=0.0016$ inch $^{2}$.

yeat was included because microbial antagonists have been shown to be associated with it.

${ }^{\mathrm{x}}$ Malt served as a control.

"Fisher's least significant difference at $P=0.05$

amended with unautoclaved coir and peat within $7 \mathrm{~d}$ of setting up the experiments. Autoclaved coir and peat media and autoclaved and unautoclaved malt media did not inhibit growth of $F$. solani (Table 4).

INHIBITION OF MYCELIAL GROWTH OF SOILBORNE PATHOGENS BY A. TERREUS. A clear zone of inhibition was observed between mycelia of $A$. terreus and mycelia of S. sclerotiorum, Rhizoctonia sp., Cylindrocladium sp., Pythium sp., and Vertillium sp. This zone was not apparent in the A. terreus/Phytophthora spp. cultures. A. terreus inhibited mycelial growth of the pathogens by up to 75\% (Table 5). The least inhibition (18\%) occurred on Verticillium sp.,

Table 5. Inhibition of soilborne plant pathogens by Aspergillus terreus recovered from coir.

\begin{tabular}{|c|c|}
\hline Pathogen & Inhibition (\%) \\
\hline \multicolumn{2}{|l|}{ Phytophthora } \\
\hline parasitica & 75 \\
\hline Phytophthora capsici & 70 \\
\hline Phytophthora citricola & 67 \\
\hline \multicolumn{2}{|l|}{ Phytophthora } \\
\hline cinnamomi & 65 \\
\hline \multicolumn{2}{|l|}{ Phytophthora } \\
\hline cactorum & 56 \\
\hline Fusarium solani & 55 \\
\hline \multicolumn{2}{|l|}{ Phytophthora } \\
\hline cryptogea & 46 \\
\hline \multicolumn{2}{|l|}{ Sclerotinia } \\
\hline sclerotiorum & 42 \\
\hline Rhizoctonia sp. & 37 \\
\hline Cylindrocladium sp. & 37 \\
\hline Pythium sp. & 23 \\
\hline Verticillium sp. & 18 \\
\hline $\mathrm{LSD}^{\mathrm{y}}$ & 15 \\
\hline \multicolumn{2}{|c|}{$\begin{array}{l}{ }^{2} \text { Mean of two experiments. The percentage of inhib- } \\
\text { ition was based on linear measurement of pathogen } \\
\text { cultures on half-strength potato dextrose agar plates } \\
\text { with } A \text {. terreus compared with linear measurement of } \\
\text { pathogen cultures on plates without } A \text {. terreus. } \\
{ }^{y} \text { Fisher's least significant difference at } P=0.05 \text {. }\end{array}$} \\
\hline
\end{tabular}

whereas Phytophthora species were inhibited the most (Table 5).

\section{Discussion}

PDA amended with an unsterilized coir suspension strongly suppressed growth of $P$. capsici, regardless of suspension concentration, but supported growth of several microorganisms. Suppression of $P$. capsici was likely due to competition by these microorganisms for space and nutrients. Although chemical inhibition of $P$. capsici was not investigated, it apparently played little or no role in suppression because PDA amended with a filter-sterilized coir suspension did not inhibit growth of the pathogen at all concentrations of the suspension. The facts that microorganisms did not grow on PDA amended with a filter-sterilized coir suspension and growth of $P$. capsici on this medium was not inhibited imply that microorganisms played a significant role in pathogen suppression on PDA amended with an unsterilized coir suspension.

It was interesting to note that amending PDA with the highest concentration of the filter-sterilized coir suspension $(0.4 \mathrm{~mL}$ suspension per milliliter of PDA) resulted in significantly greater $(P=0.05) P$. capsici mycelium-covered area than amending PDA with lower concentrations of the suspension $(0.1$ or $0.2 \mathrm{~mL}$ suspension per milliliter of PDA; Table 1). It is likely that the coir suspension contained nutrients used by $P$. capsici. The greater myceliumcovered area at the highest coir suspension concentration compared with the two lower concentrations was likely due to a higher concentration of nutrients per unit volume of PDA.

Regardless of soaking period, the lowest concentration $(0.1 \mathrm{~mL}$ suspension per milliliter of PDA) of unsterilized coir suspension effectively inhibited the growth of $P$. capsici. This implies that the population of microorganisms was sufficiently high at this concentration or the microorganisms multiplied rapidly after initiation of cultures.

WA amended with unautoclaved coir or peat completely inhibited the growth of $F$. solani, but allowed the growth of various microorganisms. On the other hand, WA amended with autoclaved coir, peat, or unautoclaved malt extract allowed the growth of $F$. solani and microorganisms did not grow on these media, implying that microorganisms played a significant role in suppressing the growth of F. solani on WA amended with unautoclaved coir or peat.

$A$. terreus was consistently isolated from coir and strongly inhibited mycelial growth of soilborne plant pathogens, especially Phytophthora species. This finding is supported by the work of Almassi et al. (1996), who found that a strain of $A$. terreus isolated from organic mulch inhibited the growth of $P$. cinnamomi and produced an antifungal metabolite, terrecyclic acid A, when grown in liquid culture. In this study, a clear zone of inhibition was observed when $A$. terreus was cultured in the same petri plate with some of the pathogens tested, implying that the inhibition may have been due in part to the production of a diffusible compound.

Isolation of A. terreus, Paeciliomyces sp., and Trichoderma sp. from coir in this study is in agreement with a recent study (Waller et al., 2008) in which 29 different species of fungi were identified in 38 substrates, which included six coir substrates. Fungi found in coir included Trichoderma viride, Paeciliomyces fumosoroseus, Galactomyces geotrichum, Eupenicillium 
reticulisporum, and several Penicillium species (Waller et al., 2008).

Candole and Evans (2004) demonstrated that when tomato seedlings were grown in coir, the incidence of damping off was reduced by $88 \%$, $90 \%$, and $41 \%$ for P. capsici, P. nicotianae, and P. aphanidermatum, respectively, compared with peat. Our study complements the study of Candole and Evans (2004) by demonstrating in vitro that coir can suppress soilborne plant pathogens and that this suppression is largely due to microorganisms associated with the substrate.

\section{Literature cited}

Almassi, F., E.L. Ghisalberti, B.W. Skelton, and A.H. White. 1996. Molecular structure of terrecyclodiol: A derivative of the antifungal metabolite terrecyclic acid A from Aspergillus terreus. J. Nat. Prod. 59:59-61.

Candole, B. and M. Evans. 2004. Suppression of soil-borne diseases caused by Pythium and Phytophthora species in coconut coir-based substrates. HortScience 39:665-666 (abstr.).

Gomez, K.A. and A.A. Gomez. 1984. Statistical procedures for agricultural research. 2nd ed. Wiley, New York.

Han, D.Y., D.L. Coplin, and H.A.J. Hoitink. 1998. Partial characterization of systemic acquired resistance induced in radish by Pantoea agglomerans strain E278Ar. Phytopathology 88:S36 (abstr.).

Hoitink, H.A.J. and M.J. Boehm. 1999 Biocontrol within the context of soil microbial communities: A substratedependent phenomenon. Annu. Rev. Phytopathol. 37:427-446.

Hoitink, H.A.J. and P.C. Fahy. 1986. Basis for the control of soilborne plant pathogens with composts. Annu. Rev. Phytopathol. 24:93-114.

Islam, M.S., S. Khan, T. Ito, T. Maruo, and Y. Shinohara. 2002. Characterization of the physico-chemical properties of environmentally friendly organic substrates in relation to rockwool. J. Hort. Sci. Biotechnol. 77:143-148.

Masago, H., M. Yoshikawa, M. Fukada, and N. Nakanishi. 1977. Selective inhibition of Pythium spp. from soil and plants. Phytopathology 67:425-428.

Meerow, A.W. 1994. Growth of two subtropical ornamentals using coir (coconut mesocarp pith) as a peat substitute. HortScience 29:1484-1486.

Meerow, A.W. 1995. Growth of two tropical foliage plants using coir dust as a container medium amendment. HortTechnology 5:237-239.

Nash, S.M. and W.C. Snyder. 1962. Quantitative estimations by plate counts of prop- agules of the bean root rot Fusarium in field soils. Phytopathology 52:567-572.

Neena, C., P.S. Ambily, and M.S. Jisha. 2007. Anaerobic degradation of coconut husk leachate using UASB-reactor. J. Environ. Biol. 28:611-615.

Postma, J., M.J.E.I. Willemsen-de Klein, and J.D. van Elsas. 2000. Effect of the indigenous microflora on the development of root and crown rot caused by Pythium aphanidermatum in cucumber grown on rockwool. Phytopathology 90:125-133.

Prasad, M. 1997. Physical, chemical and biological properties of coir dust. Acta Hort. 450:21-29.

Tsao, P.H. and S.O. Guy. 1977. Inhibition of Mortierella and Pythium in a Phytophthora isolation medium containing hymexazol. Phytopathology 67:796801 .

van der Gaag, D.J. and G. Wever. 2005. Conduciveness of different soilless growing media to Pythium root and crown rot of cucumber under near-commercial conditions. Eur. J. Plant Pathol. 112:31-41.

Waller, P.L., C.R. Thornton, D. Farley, and A. Groenhof. 2008. Pathogens and other fungi in growing media constituents. Acta Hort. 779:361-365.

Zachariah, E.J. and V. Muralidharan. 2002. Biogas recovery from coconut husk retting. Pacific Asian J. Energy 12:181-185. 